\title{
Susceptibility of the Australian freshwater crayfish Cherax destructor albidus to white spot syndrome virus (WSSV)
}

\author{
Brett F. Edgerton* \\ Centre for Marine Studies, University of Queensland, St Lucia, Queensland 4072, Australia
}

\begin{abstract}
Cherax destructor occurs naturally and/or is farmed in all Australian mainland states and territories and is of major cultural, economical and conservation significance. The aim of this study was to determine susceptibility of the commercially important subspecies C. destructor albidus to white spot syndrome virus (WSSV), a hazard to crustaceans and currently considered to be exotic to Australia. In challenge tests by intramuscular injection, C. destructor albidus displayed a similar level of susceptibility to white spot disease (WSD) as Penaeus monodon (i.e. 100\% mortality in 3 d). In one oral challenge test where $C$. destructor albidus was subjected to significant temperature stress, over $50 \%$ died of severe WSD within $14 \mathrm{~d}$ post challenge. All dead and moribund crayfish displayed histopathological lesions typical for WSD and gave positive results for WSSV in DNA dot blot hybridization tests. Survivors to $30 \mathrm{~d}(\mathrm{n}=3)$ showed no lesions and gave negative dot blot test results. In a second oral challenge test without temperature stress, mortality was delayed but reached $75 \%$ by $30 \mathrm{~d}$. However, no typical WSD lesions were observed in the dead, dying or surviving crayfish and dot blot test results were negative. The results suggested that $C$. destructor albidus would be less susceptible than $P$. monodon to WSSV exposure via natural routes of infection in farms and in the wild. This information may be useful for disease import risk analysis for WSSV.
\end{abstract}

KEY WORDS: Freshwater crayfish - Cherax destructor albidus . White spot syndrome virus . Susceptibility $\cdot$ Import risk analysis

\section{INTRODUCTION}

Australia ranks second to North America as the world's leader in number of freshwater crayfish species (Taylor 2002) and has the largest (Astacopsis gouldi) and probably the smallest (Parastacoides) species in the world. All belong to the Family Parastacidae and include 10 of the 14 known genera. Approximately $30 \%$ belong to the genus Cherax (Taylor 2002). Of the Cherax species, 3 are farmed commercially in Australia and in other tropical and subtropical regions of the world. C. destructor (Austin 1996a,b) displays the widest natural geographic range, occurring in eastern and central mainland states and territories of Australia, including its largest and most ecologically significant freshwater ecosystem, the Murray-Darling River Basin.
It is a subsistence food for some aboriginal Australians (Lawrence \& Jones 2002), and remains have been identified in the cooking hearths of Australian aboriginals dating back 28000 yr (Holdich 2002). Its ability to adapt to a wide range of environmental conditions make it well suited to aquaculture and it is farmed in 4 states and 1 territory. Production of subspecies $C$. destructor albidus (Fig. 1) is the highest (100 and $300 \mathrm{t}$ $\mathrm{yr}^{-1}$ depending on rainfall) due to natural catches from farm dams in Western Australia (Lawrence \& Jones 2002). Semi-intensive farming occurs in Western Australia, South Australia, Victoria and New South Wales and in other subtropical regions experimenting with commercial aquaculture production.

White spot disease (WSD) has caused severe disruption to the prawn aquaculture industry in Asia since the 


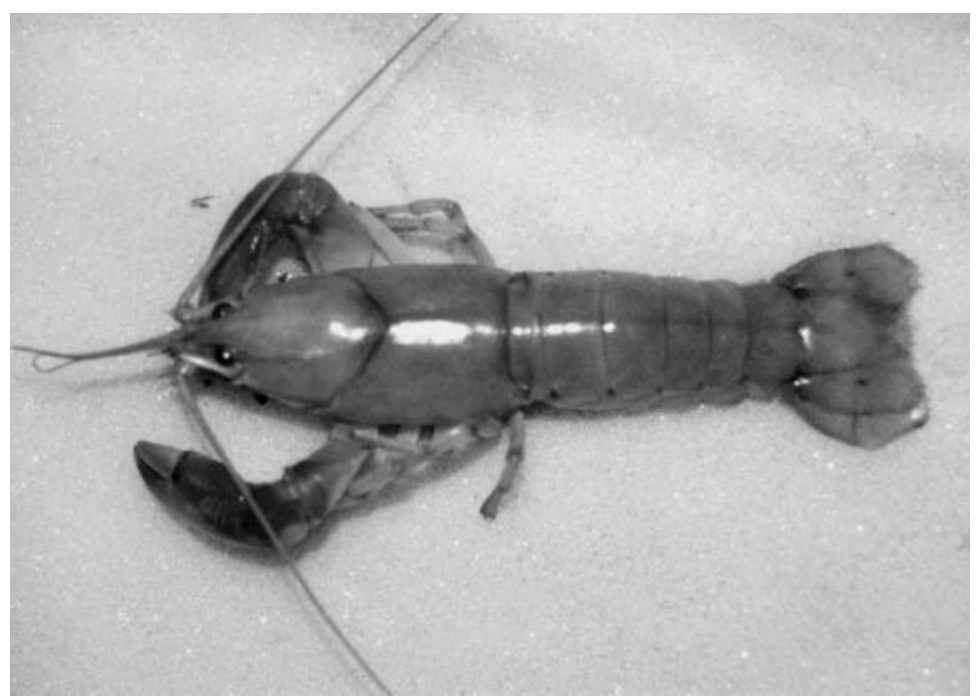

Fig. 1. Cherax destructor albidus

early 1990s (Flegel 1997) and in South America since the late 1990s (Jory \& Dixon 1999). WSD is listed by the Office International des Epizooties (OIE 2003). White spot syndrome virus (WSSV), the causative agent of WSD (Inouye et al. 1994), is a bacilliform, doublestranded DNA virus that infects mesodermal and ectodermal tissues of a wide range of crustaceans (AQIS 2000), including some species of freshwater crayfish (Richman et al. 1997, Wang et al. 1998, Corbel et al. 2001). It has recently been assigned to a new family Nimaviridae and genus Whispovirus (Mayo 2002).

WSSV is common in farmed and wild prawns and other marine crustaceans in Asia (Maeda et al. 1998, Lo \& Kou 1998) and is directly transmissible by the oral route (Wang et al. 1999, Soto \& Lotz 2001). In addition, laboratory tests have shown by ingestion and injection that WSSV-infected frozen, uncooked prawns may remain infectious for prolonged periods (Nunan et al. 1998, Wang et al. 1999). Therefore, WSSV may be considered a hazard during import risk analysis of prawns and prawn products.

There is only one international journal report on the susceptibility of an Australian freshwater crayfish Cherax quadricarinatus to WSSV (Shi et al. 2000). However, discussions with the senior author of that report (Dr. Shi Zhengli) and with Prof. Chen Xiaoxuan (Huazhong Agricultural University, Wuhan, China) revealed that the crustacean studied was not C. quadricarinatus but the American crayfish Procambarus clarkii. The only other report on the susceptibility of several Australian freshwater crayfish to an exotic pathogen was by Unestam (1976), who studied their susceptibility to Aphanomyces astaci.

Because of the scarcity of information on susceptibility of Australian crustaceans to WSSV, this study examined the susceptibility of Cherax destructor albidus to WSSV in challenge tests using WSSV-infected prawn material. The information obtained may be useful for import risk analysis (Edgerton 2002b).

\section{MATERIALS AND METHODS}

Experimental animals. Approximately 100 Cherax destructor albidus (mean weight 23 $g_{i}$ Fig. 1) from Australia were placed in styrofoam boxes with plastic bottles containing ice and delivered to Montpellier, France, in $2 \mathrm{~d}$. On arrival, they were in excellent condition (survival approximately 90\%) and were placed directly in individual aquaria containing $45 \mathrm{l}$ water and equipped with an airlift filter made of stones and polyvinyl chloride pipes, and shelters made of clay construction bricks with approximately $3 \mathrm{~cm}$ square holes. Aquaria were maintained at 25 to $26^{\circ} \mathrm{C}$ with aquarium heaters. The crayfish were acclimatized for $2 \mathrm{~d}$ before the start of challenge tests.

Viral source for challenge tests. Penaeus monodon were infected with a Thai isolate of WSSV by intramuscular injection, collected when moribund and frozen at $-50^{\circ} \mathrm{C}$ until used (within $2 \mathrm{wk}$ ). A cell-free extract was prepared by homogenising $1 \mathrm{~g}$ of soft tissues from the cephalothorax of 1 specimen in $4 \mathrm{ml}$ of Tris- $\mathrm{NaCl}$ buffer $\mathrm{pH} 7.4$ at $4^{\circ} \mathrm{C}$. The homogenate was diluted 4 -fold and clarified by centrifugation at $1600 \times g$ for $15 \mathrm{~min}$ at $4^{\circ} \mathrm{C}$. The supernatant was decanted and passed through a $0.45 \mu \mathrm{m}$ filter. The remaining $P$. monodon were macerated, refrozen at $-50^{\circ} \mathrm{C}$, and used for oral challenges.

Challenge tests. The experimental design consisted of 2 replicates of 8 crayfish each for the following 3 treatments. One group was fed on Day 0 with $5 \%$ of body weight of tissues from prawns infected with WSSV. A second group was injected in the second abdominal segment on Day 0 with $100 \mu \mathrm{l}$ of the WSSV cell-free extract. The third group comprised an untreated negative control. To validate the pathogenicity of the WSSV inocula, challenge tests were carried out with 3 groups of 5 Penaeus monodon (5 to $7 \mathrm{~g})$ maintained in three $45 \mathrm{l}$ aquaria at $28^{\circ} \mathrm{C}$. Challenge and control protocols were the same as those for the crayfish.

The crayfish were fed ad libitum daily with parboiled potato and carrots, and water exchanges were performed as required to maintain appropriate water quality. Experimental aquaria were inspected regularly, and dead or moribund crayfish were removed and recorded. The experiment was terminated on Day 30. 
WSSV detection. One or several gill filaments were removed from each dead or moribund crayfish and from each crayfish alive at the completion of the experiment. The remainder of the cephalothorax was fixed in Davidson's solution and used for histopathological analysis. The gill samples were initially frozen at $-50^{\circ} \mathrm{C}$ and then stored at $-20^{\circ} \mathrm{C}$ for 7 mo prior to analysis. The gill samples were then shipped to the Shrimp Biotechnology Business Unit, BIOTEC, Bangkok, Thailand, at ambient temperature in a solution of $80 \%$ ethanol, $20 \%$ glycerol and $0.25 \%$ mercaptoethanol for analysis by DNA dot blot hybridization.

Tissues fixed in Davidson's solution were trimmed into microcassettes, placed in $70 \%$ ethanol less than $3 \mathrm{~d}$ after initial fixation and embedded in paraffin. Five- $\mu \mathrm{m}$ thick sections were cut and stained with haematoxylin and eosin (H\&E) and examined with a light microscope for the presence and severity (SG) of WSSV lesions according to Lightner (1996).

DNA dot blot hybridization. Individual gill samples were washed 3 times with sterile distilled water and then transferred to a $1.5 \mathrm{ml}$ Eppendorf tube containing $500 \mu \mathrm{l}$ of tissue lysis buffer $(50 \mathrm{mM}$ Tris- $\mathrm{HCl}, \mathrm{pH}$ 9.0, $100 \mathrm{mM}$ EDTA, $50 \mathrm{mM} \mathrm{NaCl}, 2 \%$ SDS and $10 \mu \mathrm{g} \mathrm{ml}^{-1}$ Proteinase $\left.\mathrm{K}\right)$. The sample was then homogenised and incubated at $55^{\circ} \mathrm{C}$ for $30 \mathrm{~min}$. Total DNA was extracted by the phenol chloroform method (Sambrook \& Russell 2001). DNA in the final solution was precipitated with absolute ethanol, washed with $70 \%$ ethanol, air-dried and resuspended in $10 \mathrm{mM}$ Tris-EDTA (TE) buffer $\mathrm{pH} 8$ (Sambrook \& Russell 2001). The concentration of DNA was measured by UVspectrophotometer at 260 and $280 \mathrm{~nm}$ and adjusted to $100 \mathrm{ng}^{-1} \mathrm{l}^{-1}$ final concentration followed by storage at $-20^{\circ} \mathrm{C}$ until used.

A WSSV 232 bp PCR amplicon (Tongchuea 1996) was labelled with digoxigenin11-deoxyuridine triphosphate (dUTP) (DIG-dUTP) by replacement of the normal deoxyribonucleotide triphosphate (dNTP) reagent with a dNTP mixture containing DIG-dUTP (PCR DIG Labelling Mix from Roche) in the PCR reaction mixture. The labelled PCR product was then purified using a High Pure PCR product purification kit (Roche).

The DNA samples were dotted onto a nylon membrane using a vacuum blotting system (BioLab) and then hybridized with the WSSV DIG-dUTP-labelled probe. The concentration of probe for hybridization was $10 \mathrm{ng} \mathrm{ml}^{-1}$. Hybridization was carried out for $8 \mathrm{~h}$ at $68^{\circ} \mathrm{C}$ and membranes were washed twice for 5 min each at room temperature, then twice for $15 \mathrm{~min}$ each at $68^{\circ} \mathrm{C}$. Colorimetric detection was performed using a DIG nucleic acid detection kit based on antidigoxygenin alkaline phosphatase conjugate according to the manufacturer's directions (Roche). A positive reaction gave insoluble blue-black precipitate with the nitroblue tetrazolium salt substrate.

\section{RESULTS}

\section{Challenge tests}

Penaeus monodon injected with WSSV gave $100 \%$ mortality within 2 d post injection (p.i.). By oral challenge, the first deaths occurred at $3 \mathrm{~d}$ p.i. and mortality was $100 \%$ at $4 \mathrm{~d}$. No P. monodon in the untreated control group had died by test termination Day 8 .

By injection challenge, the first dead Cherax destructor albidus were detected at $2 \mathrm{~d}$ p.i. and mortality was $100 \%$ at 3 d p.i. (Table 1). Moribund crayfish lay

Table 1. Survival and diagnostic data for each Cherax destructor albidus from a transmission trial with white spot syndrome virus (WSSV). SG: severity grade of infection; nd: not done due to cannibalism/decomposition. Note that 1 crayfish from Replicate 1 of the oral challenge group was discounted as it was found decayed with its claw stuck in a hide

\begin{tabular}{|c|c|c|c|c|c|c|c|c|}
\hline \multirow{2}{*}{$\begin{array}{l}\text { Treat- } \\
\text { ment }\end{array}$} & \multicolumn{4}{|c|}{ Replicate 1} & \multicolumn{4}{|c|}{ Replicate 2} \\
\hline & No. & $\begin{array}{c}\text { Day } \\
\text { collected }\end{array}$ & $\begin{array}{l}\text { Histology } \\
\text { (SG?/-) }\end{array}$ & $\begin{array}{l}\text { Dot } \\
\text { blot }\end{array}$ & No. & $\begin{array}{c}\text { Day } \\
\text { collected }\end{array}$ & $\begin{array}{l}\text { Histology } \\
\text { (SG?/-) }\end{array}$ & $\begin{array}{l}\text { Dot } \\
\text { blot }\end{array}$ \\
\hline \multirow[t]{8}{*}{ Control } & 1 & 1 & - & - & 1 & 14 & nd & nd \\
\hline & 2 & 23 & nd & - & 2 & $30^{\mathrm{a}}$ & - & - \\
\hline & 3 & $30^{\mathrm{a}}$ & - & - & 3 & $30^{\mathrm{a}}$ & - & - \\
\hline & 4 & $30^{\mathrm{a}}$ & - & - & 4 & $30^{\mathrm{a}}$ & - & - \\
\hline & 5 & $30^{\mathrm{a}}$ & - & - & 5 & $30^{\mathrm{a}}$ & - & - \\
\hline & 6 & $30^{\mathrm{a}}$ & - & - & 6 & $30^{\mathrm{a}}$ & - & - \\
\hline & 7 & $30^{\mathrm{a}}$ & - & - & 7 & $30^{\mathrm{a}}$ & - & - \\
\hline & 8 & $30^{\mathrm{a}}$ & - & - & 8 & $30^{\mathrm{a}}$ & - & - \\
\hline \multirow[t]{8}{*}{ Injection } & 1 & 2 & SG4 & + & 1 & 2 & SG4 & + \\
\hline & 2 & 2 & SG4 & + & 2 & 2 & SG4 & + \\
\hline & 3 & 2 & SG4 & + & 3 & 2 & SG4 & + \\
\hline & 4 & 2 & SG4 & + & 4 & 2 & SG4 & + \\
\hline & 5 & 2 & SG4 & + & 5 & 2 & SG4 & + \\
\hline & 6 & 2 & SG4 & + & 6 & 2 & SG4 & + \\
\hline & 7 & 2 & SG4 & + & 7 & 3 & SG4 & + \\
\hline & 8 & 2 & SG4 & + & 8 & 3 & SG4 & + \\
\hline \multirow[t]{8}{*}{ Oral } & 1 & 6 & SG4 & + & 1 & 1 & - & - \\
\hline & 2 & 7 & SG4 & + & 2 & 18 & - & - \\
\hline & 3 & 11 & SG4 & + & 3 & 18 & - & - \\
\hline & 4 & 14 & SG4 & + & 4 & 18 & - & - \\
\hline & 5 & $30^{\mathrm{a}}$ & - & - & 5 & 24 & nd & - \\
\hline & 6 & $30^{\mathrm{a}}$ & - & - & 6 & 27 & - & - \\
\hline & 7 & $30^{\mathrm{a}}$ & - & - & 7 & $30^{\mathrm{a}}$ & - & - \\
\hline & & & & & 8 & $30^{\mathrm{a}}$ & - & - \\
\hline
\end{tabular}


on their backs waving their pleopods for several hours prior to death. No other clinical signs of disease were observed. In oral challenges, the infected prawn tissue was rapidly consumed. One crayfish in Replicate 1 died at $4 \mathrm{~d}$ post challenge, but it was in an advanced state of decay with its claw stuck in a hide. It was excluded from the analysis. In this replicate, 1 dead crayfish was detected on each of Days 6, 7, 11 and 14 post challenge and 3 survived to trial completion at $30 \mathrm{~d}(57 \%$ mortality). By error, the aquarium heater for this replicate was switched off overnight between Days 4 and 5 and the temperature dropped to $16^{\circ} \mathrm{C}$ over a $24 \mathrm{~h}$ period before restoration to $26^{\circ} \mathrm{C}$. For Replicate 2, 1 dead crayfish was found at Day 1 post challenge, 3 on Day 18 and 1 each on Days 24 and 27 (75\% mortality). No clinical signs of disease were observed in the oral challenges. Survival in the control group was $81 \%$ at completion of the trial.

\section{Histological detection of WSSV after injection challenge}

By histology, all Cherax destructor albidus injected with WSSV displayed systemic SG4 lesions characteristic of WSSV (Lightner 1996), i.e. showing cell nuclei with marginated chromatin and small eosinophilic to large pale basophilic intranuclear inclusions. WSSV inclusions were most common in the cuticular epithelia of the general, foregut and hindgut exoskeleton and in connective tissues. Other infected tissues included myocardium, epicardium, neural tissue, gonads, cells associated with haemolymph vessels in the hepatopancreas and striated muscle. WSSV inclusions were generally less common in the antennal gland epithelia, gill epithelia, mandibular organ, oviduct and haemopoietic tissues, with the exception of a few individuals.

\section{Histological detection of WSSV after oral challenge}

In Replicate 1 of the WSSV oral challenge test, all dead or moribund crayfish displayed SG4 inclusions in the same tissues as described above (Fig. 2) for the injection trial. In some of these crayfish, almost $100 \%$ of cells in large areas of the cuticular epithelium of the mandibles, oesophagus, foregut epithelium and nephridial canal of the antennal gland showed nuclei typical for WSSV infection and there was significant concomitant tissue disruption. WSSV lesions were not detected in H\&E sections of the 3 surviving crayfish from Replicate 1, nor in any dead or surviving crayfish in Replicate 2. Nor were WSSV lesions detected in any crayfish in the control group.

\section{Detection of WSSV by DNA dot blot hybridization}

The results of the dot blot analyses were consistent with the histology results. All of the crayfish positive by histology were also positive by dot blot hybridization while those negative by histology were negative by dot blot hybridization. The dot blot hybridization procedure was performed twice with identical results.

\section{DISCUSSION}

Since all the Cherax destructor albidus injected with WSSV developed severe infections and died within $3 \mathrm{~d}$, while Penaeus monodon of one-third their weight died within $2 \mathrm{~d}$, it may be concluded that both species are highly susceptible to WSD by injection. Results from per os challenge were more complex. Only the 4 crayfish exposed to temperature stress (Replicate 1) displayed histological lesions typical for WSSV following oral challenge. They were also the only specimens to give positive DNA dot blot hybridization test results. It is possible that low temperature may be a trigger for WSD as has been reported for $P$. vannamei (Vidal et al. 2001). Mortality in Replicate 2 without temperature stress could not be clearly assigned to WSSV because of the lack of pathognomonic lesions and negative DNA dot blot hybridization results. Another pathogen may have been the cause. Unfortunately, the quality of the histological preparations was compromised by the advanced autolytic state since most of the crayfish were dead when collected. This precluded detection of subtle pathological changes. The first crayfish to die in this replicate (Day 1 p.i.) displayed severe necrosis in the ventral nerve chord, and many that died later displayed haemocytic aggregates in connective tissue, especially in the hepatopancreas. This may have been analogous to the pathological changes observed in prawns chronically infected by WSSV (Wang et al. 1999). Mortality due to unknown causes is a common problem with challenge studies on crustaceans derived from wild seed since most are known to carry multiple viral pathogens (Flegel 2001).

These difficulties may have been overcome in a new series of trials, especially if cool water temperatures had been used, but prohibitive costs and arrangements for international transport of crayfish made this impossible. Despite the complications in the oral challenge test, the observations in this study are similar to those published for other freshwater crayfish species. Corbel (2000) observed roughly 70 and $90 \%$ mortality at $22 \mathrm{~d}$ for native European crayfish Astacus leptodactylus and native American crayfish Orconectes limosus, respectively, injected with WSSV. These crayfish exhibited the slowest mortality rate of 8 decapods injected with 

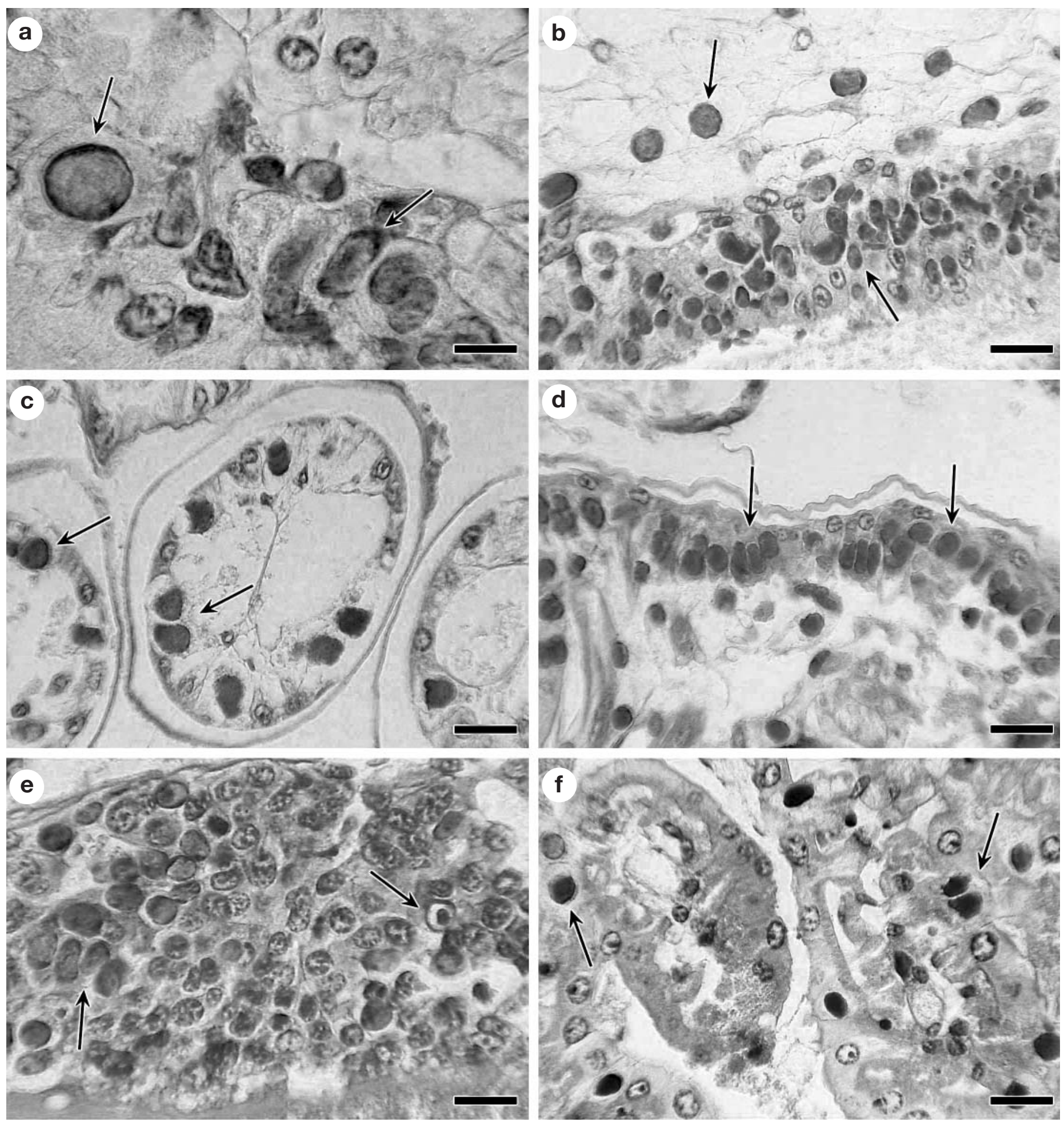

Fig. 2. Cherax destructor albidus with severe infections by white spot virus following per os exposure (scale bar relevant to all; H\&E). $(\mathrm{a}, \mathrm{b})$ Infected cells displaying margination of chromatin and small eosinophilic or hypertrophic pale basophilic inclusions (arrows) in the foregut epithelium (scale bars $=20$ and $50 \mu \mathrm{m}$, respectively). (c) Gill epithelium (scale bar $=50 \mu \mathrm{m})$. (d) Hindgut epithelium $(\mathrm{scale}$ bar $=50 \mu \mathrm{m})$. (e) Haemopoietic tissue (scale bar $=40 \mu \mathrm{m}$ ). (f) Antennal gland (scale bar $=50 \mu \mathrm{m}$ ) 
WSSV while the crab Carcinus maenus did not die. Mortality for the commercially important native American species Procambarus clarkii (Wang et al. 1998) was similar.

The outcome of pathogen challenge is determined by many interacting factors including host species, biology, age and health. However, based on the results herein and on published data from trials conducted with several decapods, it appears that freshwater crayfish may have a lower level of susceptibility to WSD than do many other decapods such as penaeid prawns (Edgerton 2002a). Freshwater prawns are also less susceptible to WSD than penaeid prawns (Sahul Hameed et al. 2000, Pramod Kiran et al. 2002). The finding of cells infected by WSSV in the gonads of Cherax destructor albidus suggests the potential for vertical transmission, as has been reported for penaeid prawns (Hsu et al. 1999).

\section{CONCLUSIONS}

In conclusion, this study has shown that Cherax destructor albidus and a penaeid prawn species display a similar level of susceptibility to WSD in laboratory injection trials but that $C$. destructor albidus was less susceptible to WSD by oral challenge. This in turn suggests that $C$. destructor albidus would be less susceptible to WSD in farms and in the wild than penaeid prawns in equivalent environs.

Acknowledgements. Freshwater crayfish shipments were procured and/or organised by B. Jones, P. Hillier (Department of Fisheries Government of Western Australia), M. Wingfield (Queensland Department of Primary Industries), R. Callinan, D. Gilligan, A. Sanger and L. Rava (NSW Fisheries). This was a significant undertaking given the logistic issues involved, and the perseverance of this group is very much appreciated (especially B. J. and P. H., who sent 3 shipments). The WSSV isolate was provided by S. Durand (University of Montpellier 2). Fig. 1 has been modified from a graphic file supplied by $M$. Wingfield. This research was conducted whilst the author was in receipt of a Research Fellowship from the Centre National de la Recherche Scientifique and was hosted by J.-R. Bonami and P. Roch. This project was funded as an external consultancy to Agriculture, Fisheries and ForestryAustralia, contract No. AB01-027.

\section{LITERATURE CITED}

Austin CM (1996a) Systematics of the freshwater crayfish genus Cherax Erichson (Decapoda: Parastacidae) in south-western Australia: electrophoretic, morphological and habitat variation. Aust J Zool 44:223-258

Austin CM (1996b) Systematics of the freshwater crayfish genus Cherax Erichson (Decapoda: Parastacidae) in northern and eastern Australia: electrophoretic and morphological variation. Aust J Zool 44:259-296
Corbel V (2000) Potential hosts for WSSV (white spot syndrome virus) in European waters. Postgraduate thesis, University of Montpellier II, Montpellier

Corbel V, Zuprizal, Shi Z, Huang Z, Arcier JM, Bonami JR (2001) Experimental infection of European crustaceans with white spot syndrome virus (WSSV). J Fish Dis 24: $377-382$

Edgerton BF (2002a) A review of international biosecurity policy development in relation to movements of freshwater crayfish. Bull Fr Peche Piscic 367(4):805-812

Edgerton BF (2002b) Hazard analysis of exotic pathogens of potential threat to European freshwater crayfish. Bull Fr Peche Piscic 367(4):813-822

Flegel TW (1997) Special topic review: major viral diseases of the black tiger prawn (Penaeus monodon) in Thailand. World J Microbiol Biotechnol 13(4):433-442

Flegel TW (2001) The shrimp response to viral pathogens. In: Browdy CL, Jory DE (eds) The new wave. Proceedings of the special session on sustainable shrimp aquaculture, World Aquaculture 2001, Orlando. World Aquaculture Society, Baton Rouge, LA, p 190-214

Holdich DM (2002) Conclusions. In: Holdich DM (ed) Biology of freshwater crayfish. Blackwell Science, Oxford, p 673-682

Hsu HC, Lo CF, Lin SC, Liu KF and 5 others (1999) Studies on effective PCR screening strategies for white spot syndrome virus (WSSV) detection in Penaeus monodon brooders. Dis Aquat Org 39:13-19

Inouye $\mathrm{K}$, Miwa $\mathrm{S}$, Oseko N, Nakano $\mathrm{H}$, Kimura T, Momoyama K, Hiraoka M (1994) Mass mortalities of cultured kuruma shrimp Penaeus japonicus in Japan in 1993: electron microscopic evidence of the causative virus. Fish Pathol 29(2):149-158

Jory DE, Dixon HM (1999) Shrimp whitespot in the western hemisphere. Aquac Mag 25(3):83-91

Lawrence C, Jones C (2002) Cherax. In: Holdich DM (ed) Biology of freshwater crayfish. Blackwell Science, Oxford, p 635-669

Lightner DV (1996) A handbook of pathology and diagnostic procedures for diseases of penaeid shrimp. World Aquaculture Society, Baton Rouge, LA

Lo CF, Kou GH (1998) Virus-associated white spot syndrome of shrimp in Taiwan: a review. Fish Pathol 33(4):365-371

Maeda M, Itami T, Furumoto A, Hennig O, Imamura T, Kondo M, Hirono I, Aoki T, Takahashi Y (1998) Detection of penaeid rod-shaped DNA virus (PRDV) in wild-caught shrimp and other crustaceans. Fish Pathol 33(4):373-380

Mayo MA (2002) A summary of taxonomic changes recently approved by ICTV. Arch Virol 147:1655-1656

Nunan LM, Poulos BT, Lightner DV (1998) The detection of white spot syndrome virus (WSSV) and yellow head virus (YHV) in imported commodity shrimp. Aquaculture 160 $(1-2): 19-30$

OIE (2003) International Aquatic Animal Health Code. Office International des Epizooties, Paris

Pramod Kiran RB, Rajendran KV, Jung SJ, Oh MJ (2002) Experimental susceptibility of different life-stages of the giant freshwater prawn, Macrobrachium rosenbergii (de Man), to white spot syndrome virus (WSSV). J Fish Dis 25:201-207

Richman LK, Montali RJ, Nichols DK, Lightner DV (1997) A newly recognized fatal baculovirus infection in freshwater crayfish. In: Proceedings of the American Association of Zoo Veterinarians, 1997. Abstracts

Sahul Hameed AS, Xavier Charles M, Anilkumar M (2000) Tolerance of Macrobrachium rosenbergii to white spot syndrome virus. Aquaculture 183:207-213 
Sambrook J, Russell DW (2001) Molecular cloning. A laboratory manual. 3rd edn. Cold Spring Harbor Laboratory Press, Cold Spring Harbor, NY

Shi Z, Huang C, Zhang J, Chen D, Bonami JR (2000) White spot syndrome virus (WSSV) experimental infection of the freshwater crayfish Cherax quadricarinatus. J Fish Dis 23:285-288

Soto MA, Lotz JM (2001) Epidemiological parameters of white spot syndrome virus infections in Litopenaeus vannamei and L. setiferus. J Invertebr Pathol 78:9-15

Taylor CA (2002) Taxonomy and conservation status of native crayfish stocks. In: Holdich DM (ed) Biology of freshwater crayfish. Blackwell Science, Oxford, p 236-257

Tongcheua W (1996) Detection of white spot and yellow head viruses in Penaeus monodon by amplification of conserved sequences. MSc thesis, Mahidol University, Bangkok

Editorial responsibility: Timothy Flegel,

Bangkok, Thailand
Unestam T (1976) Defence reactions in and susceptibility of Australian and New Guinea freshwater crayfish to European-crayfish-plague fungus. Aust J Exp Biol Med Sci 53(5):349-359

Vidal OM, Granja CB, Aranguren F, Brock JA, Salazar M (2001) A profound effect of hyperthermia on survival of Litopenaeus vannamei juveniles infected with white spot syndrome virus. J World Aquacult Soc 32:364-372

Wang Q, White BL, Redman RM, Lightner DV (1999) Per os challenge of Litopenaeus vannamei postlarvae and Farfantepenaeus duorarum juveniles withsix geographic isolates of white spot syndrome virus. Aquaculture 170(3-4): 179-194

Wang YC, Lo CF, Chang PS, Kou GH (1998) Experimental infection of white spot baculovirus in some cultured and wild decapods in Taiwan. Aquaculture 164(1-4):221-231

Submitted: July 29, 2003; Accepted: February 14, 2004

Proofs received from author(s): May 12, 2004 